\title{
Impact of tidal height on characteristics of ALOS PALSAR measurements to estimate above ground biomass of mangrove forest in Indonesia
}

\author{
S Darmawan ${ }^{1,3,4}$, W Takeuchi ${ }^{1}$, Y Vetrita ${ }^{2}$, K Wikantika $^{3}$ and D K Sari ${ }^{4}$ \\ ${ }^{1 .}$ Institute of Industrial Science, University of Tokyo, Japan \\ 2. Indonesian National Institute of Aeronautics and Space (LAPAN), Indonesia \\ ${ }^{3}$. Center for Remote Sensing, Institut Teknologi Bandung (ITB), Indonesia \\ ${ }^{4 .}$ Institut Teknologi Nasional (ITENAS), West Java, Indonesia
}

Email: soni@iis.u-tokyo.ac.jp and soni_darmawan@yahoo.com

\begin{abstract}
KEY WORDS: Tidal height, HH, HV and biomass.
\end{abstract}
\begin{abstract}
Mangrove has the most carbon rich forests in the tropics. Mapping and monitoring biomass of mangrove forest is very important to manage ecosystem and field survey of mangrove biomass and productivity is very difficult due to muddy soil condition, heavy weight of the wood, very large area and tidal effect on mangrove area. Advanced Land Observing Satellite (ALOS) Phased Array L-band Synthetic Aperture Radar (PALSAR) is available for identification and monitoring mangrove forest. The objective of this research is to investigate the impact of tidal height on characteristics of $\mathrm{HH}$ and $\mathrm{HV}$ derived from ALOS PALSAR for estimation above ground biomass of mangrove forest. Methodology consists of collecting of tidal height data in the study area, ALOSPALSAR time series data, region of interest (ROI) on mangrove forest, characterization of $\mathrm{HH}$ and $\mathrm{HV}$ and impact analysis of tidal height on $\mathrm{HH}$ and HV. The result of this research has showed the impact of tidal height on characteristics $\mathrm{HH}$ and $\mathrm{HV}$ on mangrove forest types derived from ALOS-PALSAR and proposed the model for estimation aboveground biomass of mangrove forest.
\end{abstract}

\section{INTRODUCTION}

\subsection{Background}

Mangrove forests occur along ocean coastlines throughout the tropics, and providing important products and services. They also provide among the most in tense coastal carbon sinks in the world and play a growing and central role in the global carbon cycle (Nellemann et al., 2009). According Daniel et al. (2011) found that mangroves have a total carbon storage that is on average, five times larger than those typically observed in temperate, boreal and tropical terrestrial forests, on a perunit area basis. This suggests that mangroves play an important role in global climate change management. In order to gain and build a solid understanding of the global carbon budget and ultimately the effects of diminishing mangrove forests on climate change, it is crucial to obtain an assessment and quantification of the spatial distribution of mangrove forest biomass. Indonesia has mangrove area the largest in the world, larges area around 3.5 million ha or around $17 \%-23 \%$ from large mangrove in the world (Rusila et al., 2009). In recent years global mangrove loss of more than 50\%. Mapping and monitoring biomass of mangrove forest is very important but field survey of mangrove biomass and productivity in overall Indonesia is very difficult due to muddy soil condition, heavy weight of the wood (Takeuchi et al., 2011), large area and tidal influences.

Remote sensing has been widely proven to be essential in monitoring and mapping highly threatened mangrove ecosystems. Many research studies on this subject have been carried out around the globe. Tropical and subtropical coastal mangroves are among the most threatened and vulnerable ecosystems worldwide. According to Lucas et al. (2007) the launch of the Japanese Space Exploration Agency's (JAXA) Advanced Land Observing Satellite (ALOS) Phased Arrayed L-band SAR (PALSAR) in 2006 therefore represented a milestone in the global observation, characterization, mapping and monitoring or mangroves largely, because these provide more information on the three dimensional structure and biomass of woody vegetation and the presence and extent of (primarily tidal) inundation. As data can be day or night regardless of weather conditions, mangroves can be observed more frequently, even in regions with prevalent cloud cover. The backscattering coefficient depends upon the interactions of microwaves of varying configurations with component of the mangrove (e.g. leaves, branches and trunks) of varying size, dimension, density, orientation and dielectrics constants (moisture contents) (Lucas et al., 2007). The longer L-band microwaves have a greater likelihood of penetrating the foliage and small branches of the upper canopies of the forest and interacting with woody trunk and larger branch components as well as the underlying surface (Tsomon et al., 2002; Lucas et al.,2004). Because of mangrove occupy zones of transition 
between terrestrial and marine ecosystem that occurs in tidal forest and L-band can penetrate until underlying surface, how the impact of tidal height on characteristics of ALOS PALSAR measurement. The objective of this research is to investigate impact of tidal height on characteristics of $\mathrm{HH}$ and $\mathrm{HV}$ derived from ALOS PALSAR measurements for estimation aboveground biomass of mangrove forest.

\subsection{Site description}

Indonesia also called "Nusantara" is a country in Southeast Asia that is located on $6^{\circ} \mathrm{N}-11^{\circ} \mathrm{S}$ and $95^{\circ} \mathrm{E}-141^{\circ} \mathrm{E}$, between the Asian and Australian continents and between the Pacific and Indian Oceans. Indonesia with 17,508 islands is the largest archipelagic country in the world. Indonesia have large area around $1.904 .569 \mathrm{~km}^{2} \mathrm{which}$ population around 237,6 million people in 2012, total province is 33 provinces. (www.indonesia.go.id). Generally mangrove can be found throughout in the Indonesian archipelago. Largest mangrove is found in Papua around 1.3 million ha (38\%), Kalimantan around 978 thousand ha (28\%) and Sumatera 673 thousand ha (19\%) (Rusila et al., 1999). For this study, study area is in Banyuasin, South Sumatera (104.464 E, -1.897 N), Cilacap Central Java (108.832 E, -7.679 N) and Teluk Bintuni Papua (133.470 E, -2.525 N). Their location is representative of all mangrove forest in Indonesia. Distribution of study area is shown on figure 1.

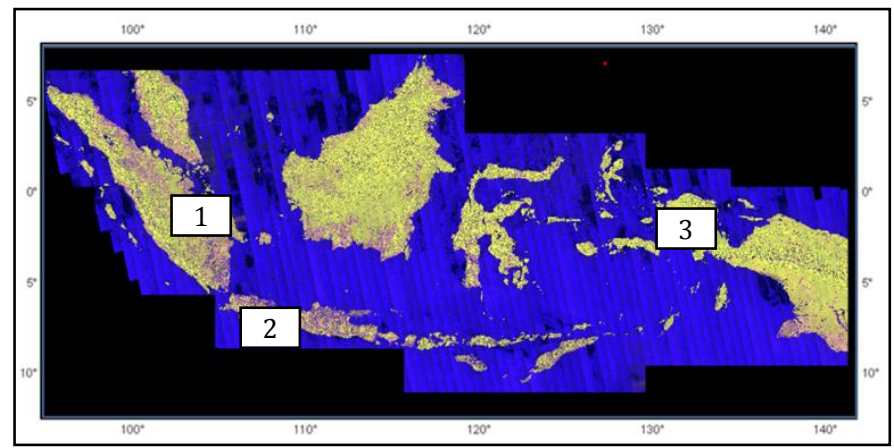

Figure 1. Study area in 1. Banyuasin, South Sumatera, 2. Cilacap, Central Java and 3. Teluk Bintuni, Papua.

\section{METHODOLOGY}

For this study, methodology consists of collecting ALOS-PALSAR, Shuttle Radar Topographic Mapping (SRTM) and tidal height, preprocessing focus on converting Digital Number to Normalize Radar Cross Sections (NRCS) and filtering, profiling and statistics, and calculating of above ground biomass estimation. The Methodology will follow on the figure 2 .

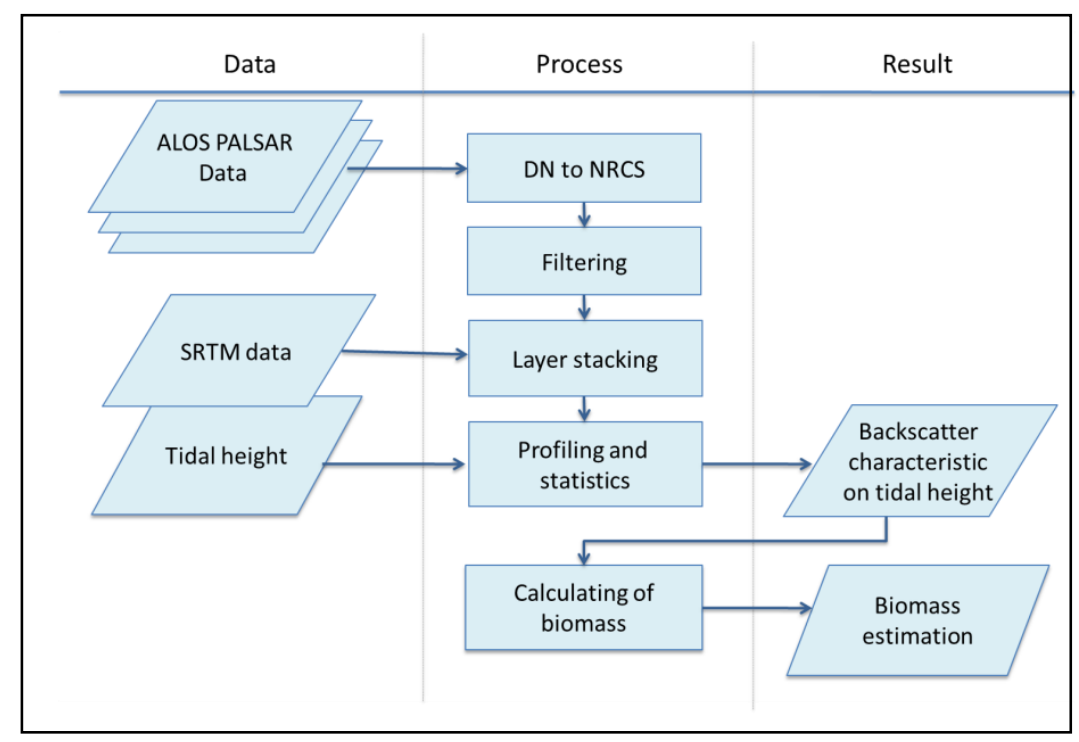

Figure 2. Methodology. 


\subsection{Data used in this study}

We have collected primary data of dual polarization ALOS PALSAR L-band HH and HV which spatial resolution $12.5 \mathrm{~m}$. Product ID H1.5GUA which radiometric and geometric corrections are performed according to the map projection, pixel spacing can be selected for the fine mode and latitudes and longitudes in the product are calculated without considering the altitude. All data were acquired in fine beam dual mode at a viewing angle of 34.3 and delivered in single-look complex (SLC) as the normalized backscattering coefficient in slant-range geometry by JAXA. For secondary data we also collected SRTM30 plus and tidal height on the study area. ALOS PALSAR data that collected in this study is described on table 1 :

Table 1. ALOS PALSAR data is used on study.

\begin{tabular}{|c|c|c|c|}
\hline Scene ID & Polarizations & $\begin{array}{l}\text { Acquisition date } \\
\text { on scene center }\end{array}$ & Location \\
\hline ALPSRP122177140 & $\mathrm{HH}$ and $\mathrm{HV}$ & $10052008-15: 48: 07.749$ & \multirow{3}{*}{$\begin{array}{c}\text { Banyuasin } \\
\text { South Sumatera }\end{array}$} \\
\hline ALPSRP128887140 & $\mathrm{HH}$ and $\mathrm{HV}$ & $25062008-15: 47: 35.329$ & \\
\hline ALPSRP142307140 & $\mathrm{HH}$ and $\mathrm{HV}$ & $25092008-15: 48: 54.632$ & \\
\hline ALPSRP129167130 & $\mathrm{HH}$ and $\mathrm{HV}$ & $25092008-15: 48: 54.632$ & \multirow{2}{*}{$\begin{array}{c}\text { Teluk Bintuni } \\
\text { Papua }\end{array}$} \\
\hline ALPSRP142587130 & $\mathrm{HH}$ and $\mathrm{HV}$ & $27062008-13: 51: 32.107$ & \\
\hline ALPSRP120717030 & $\mathrm{HH}$ and $\mathrm{HV}$ & $30042008-15: 33: 49.697$ & \multirow{3}{*}{$\begin{array}{c}\text { Cilacap } \\
\text { West Java }\end{array}$} \\
\hline ALPSRP121953770 & $\mathrm{HH}$ and $\mathrm{HV}$ & $09052008-02: 50: 03.551$ & \\
\hline ALPSRP127427030 & $\mathrm{HH}$ and $\mathrm{HV}$ & $15062008-15: 33: 31.460$ & \\
\hline
\end{tabular}

\subsection{Preprocessing and biomass estimation model}

Preprocessing focus on converting Digital Number (DN) into Normalize Radar Cross Sections (NRCS) and filtering. Converting of $\mathrm{HH}\left(\mathrm{DN}_{\mathrm{HH}}\right)$ and $\mathrm{HV}\left(\mathrm{DN}_{\mathrm{HV}}\right)$ backscatter intensities into NRCS (i.e., $\sigma_{\mathrm{HH}}^{\circ}$ and $\sigma_{\mathrm{HV}}^{\circ}$ ) based on Shimada et al. (2009) and for reducing speckle noisy used frost filtering with windows size 6x6. Converting DN into NRCS by the following equations :

$$
\begin{aligned}
& \sigma_{\mathrm{HH}}^{\circ}=10 \log _{10}\left(\mathrm{DN}_{\mathrm{HH}}^{2}\right)-83 \\
& \sigma_{\mathrm{HV}}^{\circ}=10 \log _{10}\left(\mathrm{DN}_{\mathrm{HV}}^{2}\right)-83
\end{aligned}
$$

We have collected Region of Interest (ROI) of mangrove forest based on land cover map from Indonesian Ministry of Forestry and Indonesian base map from Badan Informasi Geospasial (BIG). ROI have the shape as line profiling with long around 150 to 250 pixel. We have collected five ROI of mangrove forest from ALOS PALSAR and SRTM data for each study area and then calculate mean and standard deviation. Finally we have calculated above ground biomass following equations (Takeuchi et al., 2011) :

$$
\begin{aligned}
& \mathrm{HH}\left(\sigma^{\circ}\right)=3.6 \ln (\text { tree height })-23.7 \\
& \mathrm{HV}\left(\sigma^{\circ}\right)=4.4 \ln (\text { tree height })-24.9 \\
& \text { tree height }=2.8 \ln (\mathrm{DBH})+23.7 \\
& \mathrm{AGB}=0.25 \mathrm{DBH}^{2.46}
\end{aligned}
$$

\section{RESULTS AND DISCUSSION}

\subsection{Tidal height and topography analysis}

We have collected tidal height on the study area from http://www.ioc-sealevelmonitoring.org to know tidal height at the time ALOS PALSAR measurements. For example tidal height information derived from http://www.iocsealevelmonitoring.org is shown on figure 2. According to figure 2, ALOS PALSAR measurement at 30-04-2008 15:33:49.697 have tidal height around -0.4 meter, at 09-05-2008 02:50:03.551 have tidal height around 1.0 meter and 15-06-2008 15:33:31.460 have tidal height around -0.2 meter. According to figure 2 also variances of tidal height between -1.0 to 1.0 meter. Variances of tidal height will cause variances of flooding area at mangrove zone. Large area of flooding at mangrove zone determined also by level of topography in study area. Level of topography at study area is shown on figure 3 .

Level of topography in study area derived from SRTM 30 plus, actually SRTM have accuracy around 5 to 10 meters (Rodriguez et al., 2005). In this case we don't have topography data with more accuracy such as derived from survey terrestrial, photogrammetry or LIDAR but level of topography derived from SRTM 30 plus can describe global of level topography at study area. 


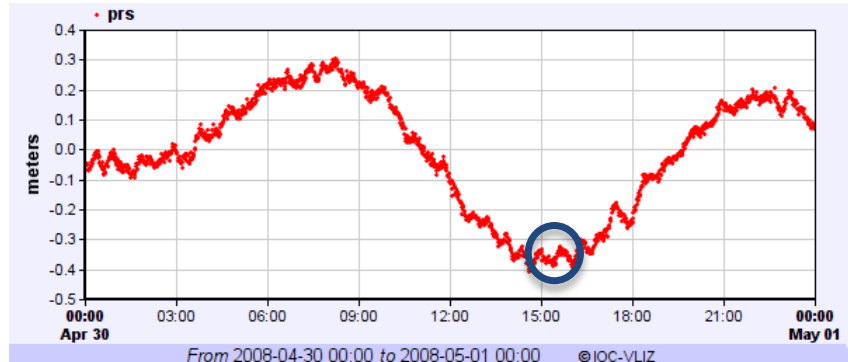

(a).Tidal height at 30-04-2008 15:33:49.697

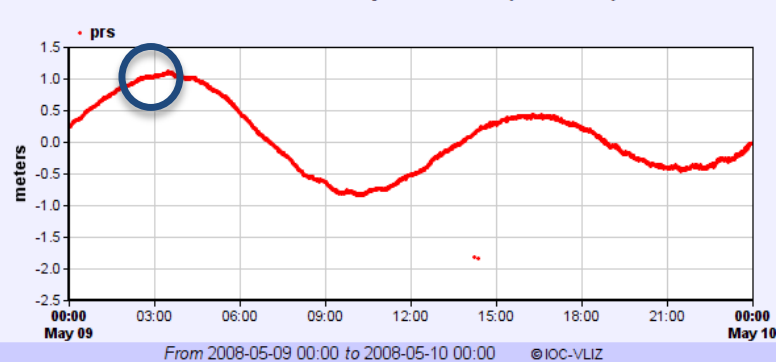

(b).Tidal height at 09-05-2008 02:50:03.551

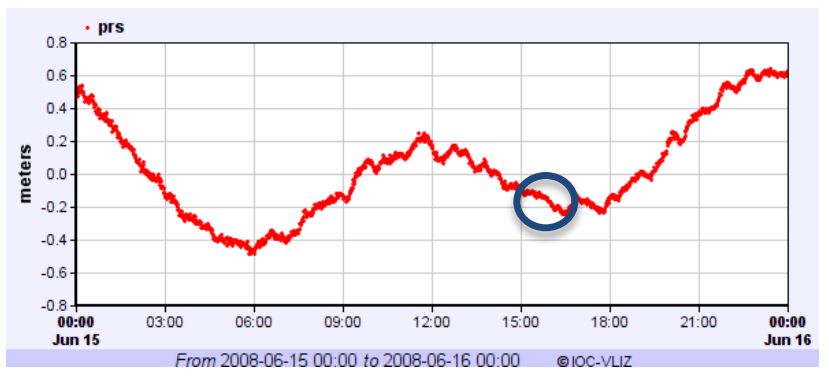

(c).Tidal height at 15-06-2008 15:33:31.460

Figure 2. Tidal height at the time ALOS PALSAR measurements in Cilacap area (source : http://www.ioc-sealevelmonitoring.org).

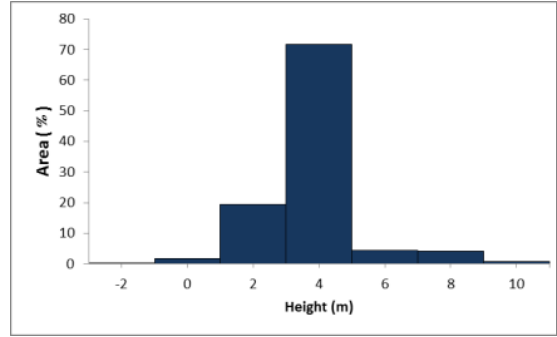

(a)

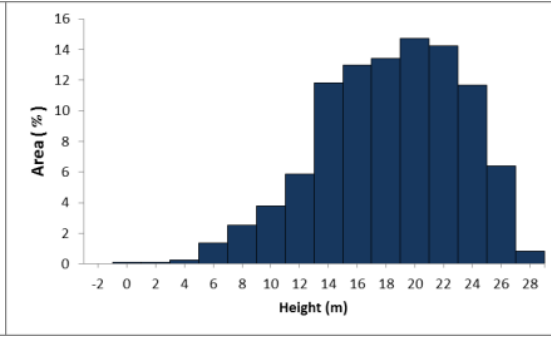

(b)

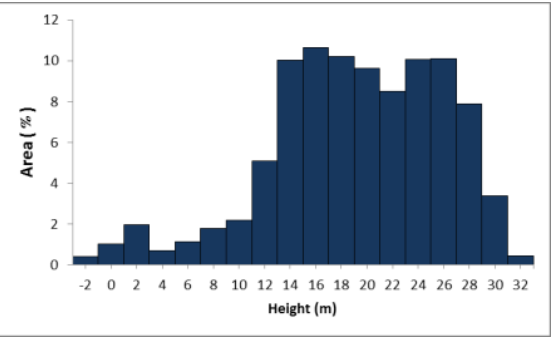

(c)

Figure 3. Level of topography at study area, (a) Cilacap, West Java,

(b) Banyuasin, South Sumatera and (c) Teluk Bintuni Papua.

According to figure 3, shown level of topography at Cilacap around 2 to 4 meter that large area around $90 \%$ from total area. It is different if compared with Banyuasin and Teluk Bintuni that have level topography more than 4 meter. It means Cilacap area has relatively flat topography that can be influenced by tidal height at all mangrove area. Effect of tidal height is based on the level of topography at Cilacap area shown on figure 4.

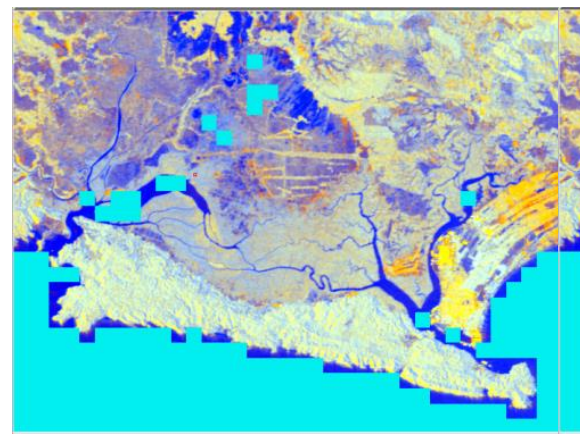

(a)

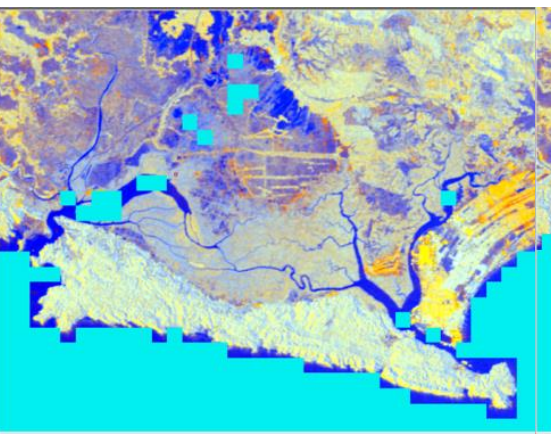

(b)

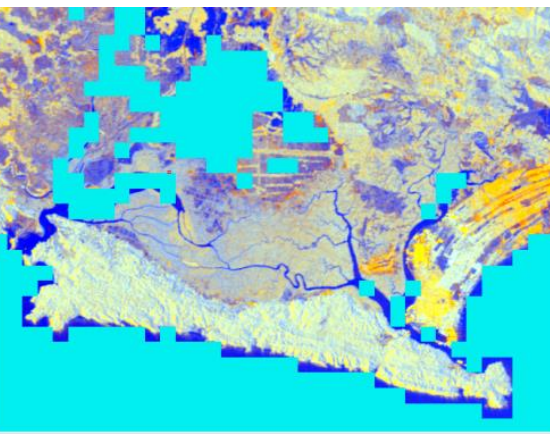

(c)

Figure 4. Illustration of flooding at mangrove area from ALOS PALSAR composite and cyan colors is water, (a) tidal height on -0.4 meter (b) tidal height on -0.2 and (c) tidal height on 1.0 meter. 
According to figure 4, describe at mangrove area with impact of tidal height on -0.4 meter (a), impact of tidal height on -0.2 meter (b) and impact of tidal height on 1 meter (c). If tidal height around 1 meter then will get more large of flooding area than tidal height only -0.4 and -0.2 meter. It means higher tide will get larger of flooding area in mangrove zone.

\subsection{Impact of tidal height on characteristics of backscatter}

Higher tide will get larger of flooding area at mangrove zone. That condition will influence backscatter value on ALOS PALSAR measurements. We have created ROI for each study area and the backscatter value on ALOS PALSAR measurement is shown on figure 5.
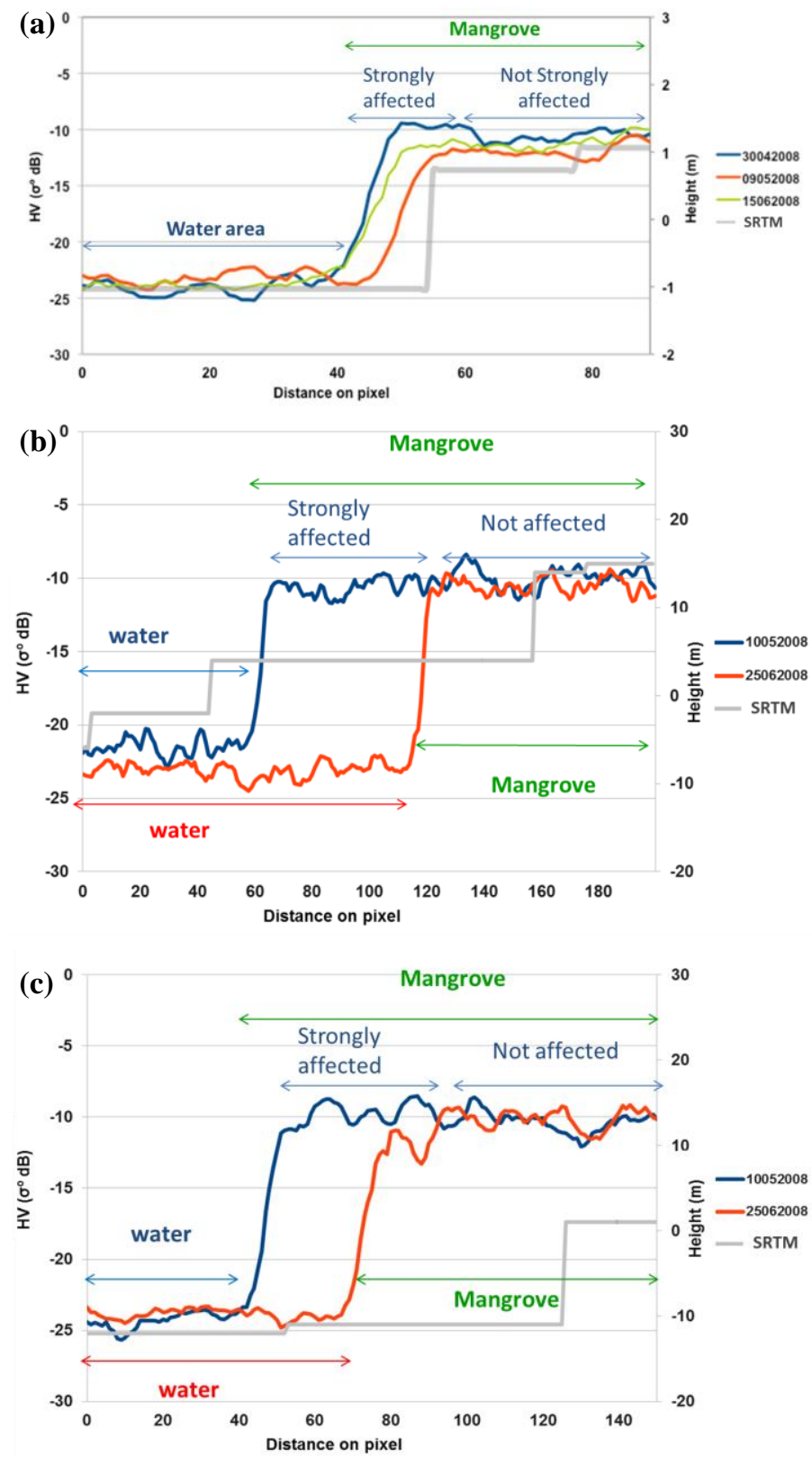

Figure 5. Impact of tidal height on characteristics of backscatter value from ALOS PALSAR measurements (a) Cilacap, West Java, (b) Banyuasin, South Sumatera and (c) Teluk Bintuni Papua.

According to figure 5, on the water area backscatter value derived from ALOS PALSAR measurement produces relatively the same value. On the boundary area between water and mangrove forest, if lower tide then the boundary area have majority of mangrove and backscatter value around $-23 \mathrm{~dB}$ until $-10 \mathrm{~dB}$ but if higher tide the boundary area have majority of water and backscatter value around $<-23 \mathrm{~dB}$. This area is found to be strongly affected by 
tidal height. Their area has level topography -1 to 1 meter, it is the same with majority of tidal height value around 1 to 1 meter. In Cilacap, mangrove forest has relatively flat topography which majority have level of topography 2 to 4 meter. Therefore tidal height not only influences on area which level of topography around -1 to 1 meter, but also on level topography 1 to 4 meter although not strongly affected by tidal height. This condition can be shown on figure 5 (a), where red lines which higher tide have lower backscatter value. On this area, the deviation value from ALOS PALSAR measurement with tidal high on -0.4 meters and 1.0 meter is around $1.6 \mathrm{~dB}$. On Banyuasin and Teluk Bintuni area, only 1-4 \% which has level of topography on 1 to 4 meters so impact of tidal height only influence on the small area.

\subsection{Above ground biomass estimation}

We have got impact of tidal height in the study area. In Cilacap because of mangrove forest has flat topography and all area got impact of tidal height so have deviation of HV value around $1.6 \mathrm{~dB}$. It is different with Banyuasin and Teluk Bintuni, their area got impact of tidal height only $4 \%$ from total area. We have calculated above ground biomass estimation using algorithm $(4,5,6)$. In Cilacap have average of $\mathrm{HV}$ value on $-16.12 \mathrm{~dB}$ with deviation value $1.6 \mathrm{~dB}$ and estimation of above ground biomass around $1.71-19.36$ ton/ha. In Banyuasin have average of $\mathrm{HV}$ value on $-14.23 \mathrm{~dB}$ and estimation of above ground biomass around $26.67 \mathrm{ton} / \mathrm{ha}$. In Teluk Bintuni have average of $\mathrm{HV}$ value on $-14.35 \mathrm{~dB}$ and estimation of above ground biomass around $23.31 \mathrm{ton} / \mathrm{ha}$. Their value still reasonable if compared with average of above ground biomass in Aceh around 11.68 ton/ha, South Sumatera 43.72 ton/ha and Riau 33.40 ton/ha (Yuwono et al., 2013) and compare with above ground biomass in Malaysia around $2.98-378$ ton/ha with average 99.40 ton/ha (Hamdan et al., 2014). For further work to make sure above ground biomass estimation on study area we will conduct and compare with field survey data.

\section{CONCLUSION}

We have showed impact of tidal height on characteristics of $\mathrm{HH}$ and $\mathrm{HV}$ derived from ALOS PALSAR for estimating aboveground biomass of mangrove forest. Tidal height has affected characteristics of ALOS PALSAR measurements. Besides impact of tidal height, backscattering value is determined also by topography on mangrove area. The deviation of backscattering value that is caused by impact of tidal height can be used to improve estimation of mangrove biomass. For future works we will conduct and compare with field survey data to create algorithm model for estimation of above ground biomass mangrove forest.

\section{ACKNOWLEDGEMENT}

This study is carried out as JAXA SAFE project.

\section{REFERENCES}

Daniel, C. D., Kauffman, J. B., Murdiyarso, D., Kurnianto, S., Sthidham, M., and Kanninen, M., 2011. Mangroves among the most carbon-rich forests in the tropics. Nature Geosciences letters, NGEO1123 (5pp).

Hamdan, O., Aziz, H. K., Hasmadi, I. H., 2014. L-Band ALOS PALSAR for biomass estimation of Matang Mangroves, Malaysia, http://dx.doi.org/10.1016/j.rse.2014.04.029.

Kuenzer, C., Bluemel, A., Gebhardt, S., Tuan Vo Quoc and Dech, S., 2011. Remote Sensing of Mangrove Ecosystems: A Review, Remote Sensing, ISSN 2072-4292 www.mdpi.com/journal/remotesensing.

Lucas, R.M., Mitchell, A., Rosenqvist, A., Proisy, C., Melius, A., Ticehurst, C., 2007. The potential of L-band SAR for quantifying mangrove characteristics and change: Case studies from the tropics. Aqua. Conserv., 17, $245-264$.

Lucas, R.M., Moghaddam, M., Cronin, N., 2004. Microwave scattering from mixed-species forest, Queensland, Australia. IEEE Transaction on Geoscience and Remote Sensing 42; 2142-2159.

Nellemann, C., Corcoran, E., Duarte, C. M., Valdes, L., De Young, C., and Fonseca, L., 2009. Blue Carbon, A rapid response assessment. Norway; United Nations Environment Programme (80 pp).

Rusila Noor, Y., M. Khazali, and I N.N. Suryadiputra, 1999. Panduan Pengenalan Mangrove di Indonesia. PHKA/WI-IP, Bogor.

Rodríguez, E., C.S. Morris, J.E. Belz, E.C. Chapin, J.M. Martin,W. Daffer, and S. Hensley, An Assessment of the SRTM Topographic Products, http://www2.jpl.nasa.gov/srtm/SRTM_D31639.pdf.

Shimada, M., Isoguchi, O., Tadono, T., Isono, K., 2009. PALSAR radiometric and geometric calibration, IEEE Transactions on Geoscience and Remote Sensing 47, 3915-3932.

Takeuchi, W., Tien, D. V., Phuong, V. T., Van, A. N., Oo, K. S., 2011. Above ground biomass mapping of mangrove forest in Vietnam by ALOS-PALSAR. ISBN 978-1-4577-1351-4 http://ieeexplore.ieee.org/ stamp/ stamp.jsp?arnumber $=06087044 \& \operatorname{tag}=1$.

Tsomon, R., Tateishi, R., Tetuko, J.S.S., 2002. A Method to estimate forest biomass and its application to monitor Mongolian Taiga using JERS-1 SAR. International Journal of Remote Sensing 23; 4971-4978.

Yuwono, D. M., Wijaya, S. W., Hidayatullah, T., Meissarah, P., Prahasta, E., and Hayatiningsih, I., 2013. Pemetaan mangrove Sumatera, Provinsi Aceh, Sumatera Utara dan Riau, Badan Infromasi Geospasial (BIG), Bogor. 